\title{
The silent killer: an assessment of level of industrial noise and associated health effects on workers
}

\author{
Omari Stephen*, De-Veer Abraham and Amfo-Otu Richard \\ Department of Environmental and Natural Resources Management, Presbyterian University College, Ghana. Akuapem Campus, \\ P. O. Box 393 Akropong-Akuapem, Ghana \\ *Corresponding author E-mail: kbrostephen@gmail.com
}

\begin{abstract}
The aim of this study is to assess the level of industrial noise and associated health effects on workers within the Tema Industrial Area, Ghana. A calibrated noise meter, Integrated Average Sound Level Meter, was used to measure noise emanating from each operating machine from plastic, can, food, and cutlass manufacturing industries within the study area. A structured questionnaire was administered to 98 workers to assess the socio-economic and health related characteristics. The results showed that mean noise levels from all 4 industries was $90.0 \mathrm{~dB}$ which exceeded the allowable level of $70 \mathrm{~dB}$ recommended for heavy industrial area. The noise levels ranged from $78.0 \mathrm{~dB}$ recorded at the food processing to $108.5 \mathrm{~dB}$ also from the same place. The results of the survey showed that most workers were aged $>30$ years. Though most of the workers were aware of the effects of noise on human health, few workers used earprotecting devices during work period. More than half $(63.3 \%)$ of workers cannot hear words clearly at normal conversation. It is clear from the study that workers were exposed to noise levels beyond recommended and they were likely to experienced auditory and non-auditory effects of such exposure.
\end{abstract}

Keywords: auditory effects, non-auditory effects, industrial noise, health-related, ear-protecting device.

\section{Introduction}

The renowned German bacteriologist, Robert Koch, noted that in future, harsh noise would become the most dangerous enemy to threaten the health of humankind [1]. Noise is an unwanted sound that has become a prominent factor in the urban environment that deteriorates the quality of life [2]. Major cities of the world are facing problems associated with rise in noise pollution due to very high population, transportation, congestion, and associated commercial and industrial activities [3, 4].

Many reports have associated noise with physiological and psychological damages. Exposure to continuous noise of 85-90 dBA, particularly over a lifetime in industrial settings, can lead to a progressive loss of hearing, with an increase in the threshold of hearing sensitivity [5]. The mechanism of noise-trauma and the damaging effects of loud sounds on the mammalian inner ear strongly are said to depend on the parameters of exposure, such as the intensity and the frequency spectrum of noise, the duration of exposure and the meaning of exposure $[6,5]$.

In 2004 alone, over 275 million people globally were reported to have had moderate-to-profound hearing impairment, $80 \%$ of them in low- and middle-income countries [7]. Chronic noise exposure is also associated with adverse pathophysiological effects and may contribute to the progression of cardiovascular disease [8, 9, 10]. There is a positive correlation between noise exposure and high blood pressure [11]. Noise, even at relatively low levels, can disrupt sleep and/or hinder cognitive development in children [12].

In fact, Ghana is not insulated from the effects of noise pollution. The noise levels in many areas in the country has, in recent times, assumed alarming rate such that the Environmental Protection Agency of Ghana has instituted April 14 ${ }^{\text {th }}$ of every year as "National Noise Awareness Day" to sensitise the public about the harmful effects of noise. Dr. E. D. Kitcher (a leading ENT Specialist Korle-Bu Teaching Hospital, Accra), speaking at the 2011 National Noise Awareness Day, described noise as a silent killer since it slowly but surely damages ones hearing. He noted that there is no medication, which can revive a dead organ of hearing or a dying organ of hearing, and therefore, efforts must be directed at creating awareness on health hazard of noise pollution [13]. 
The motivation for this study was envisaged due to insufficient information on the level of noise and associated effects industrial workers in Ghana. This study aimed at assessing the level of industrial noise and its effects on the health of workers.

\section{Materials and methods}

The study was carried out in Tema, which serves as the administrative capital of the Tema Metropolitan Assembly of Ghana. Tema is the nation's largest seaport, and the home to an oil refinery and many manufacturing centres. It is a coastal city situated 25 kilometres east of Accra, the national capital. The Greenwich Meridian (00 Longitude) passes through the city of Tema.

The noise measurements were taken in four (4) manufacturing companies: a can manufacturing, a plastic manufacturing, food and beverage manufacturing, and a cutlass manufacturing. The noise from each operating machines from the selected companies was measured using Integrated Average Sound Level Meter (CR:812B). According to a previous study, the noise meter was first calibrated and brought near the ears of the each worker operating the machine in the industries [14].

A structured questionnaire was first pretested, and then administered to 98 workers in the industries where the noise levels were measured. The questionnaire sought to know the socio-economic and noise-health related characteristics of the workers.

\section{Results}

Table 1 shows noise level recorded from machines in 4 selected manufacturing industries in Tema. Altogether, the 4 industries had mean noise level above $90 \mathrm{~dB}$. The lowest noise level of $78.0 \mathrm{~dB}$ was recorded in a food processing company from the big bag discharging system. This is a system designed for discharging a large variety of products from different types of big bags. This system is designed to eliminate dust emissions, product loss and product contamination. The same company recorded the highest noise level of $108.5 \mathrm{~dB}$ from the hammermill, which is used to aggregate materials into smaller pieces. The result shows that the noise levels recorded from all the machines used by the manufacturing companies were above the recommended level of $70 \mathrm{~dB}$ for predominantly heavy industrial areas set by the EPA-Ghana. Clearly all workers from the selected companies were exposed to these noise levels for an average of 8 hours per day.

Table 1: Noise levels recorded from selected manufacturing industries in Tema

\begin{tabular}{|c|c|c|c|c|c|c|}
\hline $\begin{array}{l}\text { Manufacturing } \\
\text { company }\end{array}$ & $\begin{array}{l}\text { Noise level (dB) } \\
\text { Machine type }\end{array}$ & mini. & Machine type & maxi. & Mean \pm SD & $\begin{array}{ll}\begin{array}{l}\text { Exposure } \\
\text { (hrs/day) }\end{array} & \text { Time }\end{array}$ \\
\hline Plastic & Compressor & 90.2 & Injection $\mathrm{m} / \mathrm{c}$ & 97.2 & $94.0 \pm 3.1$ & 8 \\
\hline Can & Smag tester & 85.6 & DRD draw & 107.0 & $94.4 \pm 7.2$ & 8 \\
\hline Food & Big bag discharging & 78.0 & Hammermill & 108.5 & $93.1 \pm 9.2$ & 8 \\
\hline Cutlass & Heat treatment & 87.5 & Polishing section & 101.4 & $93.2 \pm 4.5$ & 8 \\
\hline
\end{tabular}

Table 2 records the profile of the 98 industrial workers who responded to the questionnaire. The result shows that there are more men working as industrial workers than women and also majority of the workers were more than 30 years old. In addition, whiles most workers were married, less than a third $(32.7 \%)$ were single. Very few $(8.2 \%)$ of industrial workers had had basic education. Majority of the workers $(91.8 \%)$ had had at least secondary school education. Furthermore, most workers $(62.2 \%)$ responded to having being working with their present companies of more than 5 years whiles $38.8 \%$ for less than the same number of years. Whiles more than half $(61.2 \%)$ of the workers earned less than 500 Ghana cedis per month, the rest earned more than that amount every month. Majority (69.4\%) of the workers had registered with either company's own health insurance or the National Health Insurance Scheme (NHIS) and hence access free health delivery.

As presented in Table 3, more than half $(55.1 \%)$ of the workers regularly undergo medical check-up and of these majority (85.2\% were not told of any damage to any of their ears. Of those who have had damages of an ear, half (50\%) of them reportedly pay for treatments whiles the other half had their medical bills paid for by their employers. Though a greater number $(83.7 \%)$ of the workers were aware of the effects of noise on human health, less than half $(42.9 \%)$ of the workers used ear-protecting devices during work period. Furthermore, more (59.2\%) workers were either unaware of or did not know of routine noise monitoring at their workplaces. Whiles $36.7 \%$ of the workers said they can hear words spoken at normal voice or conversation, more than half $(63.3 \%)$ reported otherwise. 
The result showed that while more than half $(57.1 \%)$ of workers were aware of maintenance works being carried on the machinery used at the factories, less than a $28.6 \%$ were unaware of such exercise. Less than a fifth (14.3\%) said that no maintenance works had been carried out at the workplace.

Table 2: Summary of Socio-economic profile of selected industrial workers in Tema $(\mathrm{N}=98)$

\begin{tabular}{|c|c|c|}
\hline Selected characteristics & Categories & Number $(\%)$ \\
\hline \multirow[t]{2}{*}{ Sex } & Male & $56(57.1)$ \\
\hline & Female & $42(42.9)$ \\
\hline \multirow[t]{3}{*}{ Age category (years) } & $15-30$ & $8(8.2)$ \\
\hline & $31-60$ & $78(79.6)$ \\
\hline & $>60$ & $12(12.2)$ \\
\hline \multirow[t]{2}{*}{ Marital status } & Married & $66(67.3)$ \\
\hline & Single & $32(32.7)$ \\
\hline \multirow[t]{3}{*}{ Education level } & Up to basic school & $8(8.2)$ \\
\hline & Up to secondary school & $28(28.6)$ \\
\hline & Up to tertiary & $62(63.2)$ \\
\hline \multirow[t]{3}{*}{ Monthly salary (Ghana cedis) } & $<500$ & $60(61.2)$ \\
\hline & $501-1000$ & $19(19.4)$ \\
\hline & $>1000$ & $19(19.4)$ \\
\hline \multirow[t]{3}{*}{ No. of working years in the industry } & $\leq 5$ & $38(38.8)$ \\
\hline & $6-10$ & $26(26.5)$ \\
\hline & $>10$ & $34(34.7)$ \\
\hline \multirow[t]{2}{*}{ Having health insurance? } & YES & $68(69.4)$ \\
\hline & NO & $30(30.6)$ \\
\hline
\end{tabular}

Table 3: Industrial workers response to selected noise related variables $(\mathrm{N}=98)$

\begin{tabular}{|c|c|c|}
\hline Selected characteristics & Responses & Number $(\%)$ \\
\hline \multirow[t]{2}{*}{ Routine medical check-up? } & YES & $54(55.1)$ \\
\hline & NO & $44(44.9)$ \\
\hline \multirow[t]{2}{*}{ Detection of any damage to your ear? ${ }^{*}$} & YES & $8(14.8)$ \\
\hline & NO & $46(85.2)$ \\
\hline \multirow[t]{2}{*}{ Payment of treatment? $* *$} & Self & $4(50.0)$ \\
\hline & Company & $4(50.0)$ \\
\hline \multirow[t]{2}{*}{ Awareness of effects of noise on health? } & YES & $82(83.7)$ \\
\hline & NO & $16(16.3)$ \\
\hline \multirow[t]{2}{*}{ Able to hear better at normal conversation. } & YES & $36(36.7)$ \\
\hline & NO & $62(63.3)$ \\
\hline \multirow[t]{3}{*}{ Routine noise survey at workplace? } & YES & $40(40.8)$ \\
\hline & NO & $38(38.8)$ \\
\hline & Unaware & $20(20.4)$ \\
\hline \multirow[t]{2}{*}{ Provision of ear protector? } & YES & $42(42.9)$ \\
\hline & NO & $56(57.1)$ \\
\hline \multirow[t]{3}{*}{ Routine maintenance of machinery at workplace within a year? } & YES & $56(57.1)$ \\
\hline & NO & $14(14.3)$ \\
\hline & Unaware & $28(28.6)$ \\
\hline
\end{tabular}

$* \mathrm{n}=54$, from those who responded YES to medical check-up

$* * \mathrm{n}=8$, from those having ear problems

\section{Discussion}

The study revealed that workers of heavy industrial companies were exposed to noise levels exceeding the maximum allowable limit of $70 \mathrm{~dB}$ for light and predominantly heavy industrial areas which confirms the findings of other researchers and EPA Ghana $[15,16]$. These workers were likely to exhibit symptoms of long-term exposure to noise in the workplace. Several studies have examined the correlation between exposure to noise and health. 
Noise pollution has undeniable effects on worker's auditory and non-auditory functions [17]. The auditory effects include tinnitus, acoustic trauma, temporary hearing loss, permanent hearing loss, etc [17]. The non-auditory effects include cardiovascular, gastric, nervous, endocrine, psychological, autonomic, etc. It also causes both hearing loss and oxidative stress among workers exposed to high levels of noise [18]. Oxidative stress, defined as a disturbance in the balance between the production of reactive oxygen species (free radicals) and antioxidant defences [19]. It is known to cause colon cancer, cardiovascular disease, Alzheimer disease and 200 other diseases [20]. There is a positive correaltion between long-term exposure to noise and the brain organization of speech processing and attention control $[21,22]$.

The inability of most of the workers to hear words spoken to at normal conversation may be a symptom of noise exposure. People who are unable to hear and repeat words at normal voice $(\leq 40 \mathrm{~dB})$ may be suffering from moderate, severe, or profound hearing impairment [23]. Education plays a major role in people's understanding of noise and their possible effects on human health. A study has shown that many workers with low education had poor perception about noise and were unaware of its effects [24].

The use of noise or hearing protection devices will go a long way in reducing the health burden associated with occupational noise. It has been recommended that in order to reduce hearing loss, hearing loss prevention and intervention programmes should be tailored for workers at indutries and occupations with high noise exposure [25]. Comfort, requirement to wear hearing protection and enforcement of this requirement were reasons why most workers do not use hearing protection [26].

This study has shown that workers of heavy industrial companies within the Tema Metropolitan Assembly of Ghana are exposed to noise levels above the maximum allowable and this could present negative health effects on them. Though, a greater majority of them were abreast with the harmful health effects of noise, the provision of noise protection devices by employers was not encouraging. There is the need for employers to provide and enforce the use of such devices at the workplaces. Again, all stakeholders must enforce maintenance or replacement of outmoded machines.

\section{Acknowledgements}

The authors acknowledged the supports provided by management of Presbyterian University College, Ghana (PUCG). We are also grateful to the Campus Coordinator of the Akuapem Campus of PUCG, Dr. Frank Arku, for his encouragement and support. We thank the management and workers of the selected industries for allowing us to measure the sound levels and also for responding to the questionnaire.

\section{References}

[1] M. Malakootian, Noise pollution in Kerman-Iran. Iranian Journal of Public Health, vol 30, No. 1-2, (2001), $31-36$.

[2] A. Chauhan, K. K. Pande, Study of noise level in different zones of Dehradun City, Uttarakhand. Report and Opinion, vol 2, No. 7, (2010), 65-68

[3] A. Chauhan, Study of noise pollution level in different places of Haridwar and Dehraduncity (India). Environment Conservation Journal, vol 9, No. 3, (2008), 21-25.

[4] A. Chauhan, M. Pawar, D. Kumar, et al., Assessment of noise level status in different areas of Moradabad City, Report and Opinion, vol. 2, No. 5, (2010, 59-61.

[5] S. A. Stansfeld, M. P. Matheson, Noise pollution: non-auditory effects on health, Britaish Medical Bulletin, vol 68, No. 1, (2003), $243-257$.

[6] M. Sliwinska-Kowalska, U. Jedlinska, Prolonged exposure to industrial noise: cochlear pathology does not correlate with the degree of permanent threshold shift, but is related to duration of exposure, Journal of Occupational Health, vol. 40, (1998), $123-131$.

[7] World Health Organization. Deafness and hearing impairment. http://www.who.int/mediacentre/factsheets/fs300/en/index.html. (2012). Accessed April 1,2012.

[8] S. N. Willich, K. Wegscheider, M. Stallmann, et al., Noise burden and the risk of myocardial infarction, European Heart Journal, vol 27, No. 3, (2006), 276-282.

[9] I. Bendokiene, R. Grazuleviciene, A. Dedele, Risk of hypertension related to road traffic noise among reproductive-age women, Noise and Health, vol 13, No. 55, (2011), 371-377.

[10] W. Babisch, Traffic noise and cardiovascular disease: epidemiological review and synthesis, Noise and Health, vol 2, No. 8, (2000), 9-32.

[11] L. Barregard, E. Bonde, E. Ohrstrom, Risk of hypertension from exposure to road traffic noise in a population-based sample, Occupational and Environmental Medicine, vol 66, No. 6, (2009) 420-415.

[12] M. S. Sultana, N. Jahana, M. S. Islam, et al., Assessment of noise pollution in the Ashuganj Fertilizer Industrial Area, Ashuganj. Bangladesh Journal of Scientific and Industrial Research, vol 46, No. 2, (2011), 183-190.

[13] EPA-Ghana. National noise awareness day 2011. http://www.epa.gov.gh/index.php?option=com_content\&view=article\&id=235:nationalnoise-awareness-day\&catid=60:latest-news\&Itemid=113. 2011. Accessed September 15, 2011.

[14] M. A. Khuraibet, F. Al- Attar, Preliminary assessment of indoor industrial noise pollution in Kuwait. The Environmentalist, vol 20, No. 4, (2000), 319-324.

[15] EPA-Ghana. Ambient noise level guidelines on residential areas, Accra 2008.

[16] P. K. Essandoh, F. A. Armah, E. K. Afrifa, et al., Determination of ambient noise levels and perception of residents in halls at the University of Cape Coast, Ghana, Environment and Natural Resources Research, Vol 1, No. 1, (2011), 181-188. 
[17] C. H. Ni, Z.Y. Chen, Y. Zhou, et al., Associations of blood pressure and arterial compliance with occupational noise exposure in female workers of textile mill, Chinese Medical Journal, vol 120, No. 15, (2007), 1309-1313

[18] I. Yildirim, M. Kilinc, E. Okur, et al., The effects of noise on hearing and oxidative stress in textile workers, Industrial Health, vol 45, No. 6, (2007), 743-749.

[19] D. J. Betteridge, What is oxidative stress?, Metabolism, vol 49, No. 2 suppliment 1, (2000), 3-8.

[20] B. M. Hybertson, B. Gao, S. K. Bose, et al., Oxidativestress in health and disease: The therapeutic potential of Nrf2 activation, Molecular Aspects of Medicine, vol 32, No. 4-6, (2011), 234-246.

[21] T. Kujala, E. Brattico, Detrimental noise effects on brain's speech functions, Biological Psychology, vol 81, No. 3, (2009), $135-143$.

[22] U. A. Kumar, S. Ameenudin, A. V. Sangamanatha, Temporal and speech processing skills in normal hearing individuals exposed to occupational noise, Noise and Health, vol 14, No. 58, (2012), 100-105.

[23] M. Concha-Barrientos, D. Campbell-Lendrum, K. Steenland, Occupational noise: assessing the burden of disease from work-related hearing impairment at national and local levels, Environmental Burden of Disease Series, No. 9 ed: World Health Organization, 2004.

[24] P. A. Koushki, N. Kartam, N. Al-Mutairi, Workers' perceptions and awareness of noise pollution at construction sites in Kuwait, Civil Engineering and Environmental Systems, vol 21, No. 2, (2004) 127-136.

[25] S. Tak, R. R. Davis, G. M. Calvert, Exposure to hazardous workplace noise and use of hearing protection devices among US workersNHANES, 1999-2004, American Journal of Industrial Medicine, vol 52, No. 5, (2009), 358-371

[26] R. P. El Dib, J. L. Mathew, Interventions to promote the wearing of hearing protection. Cochrane Database of Systematic Reviews, vol 4 (2009), 1-30. 